\title{
MORPHOLOGICAL VARIABILITY IN WING SIZE AND WING SHAPE AMONG SPECIES Aphidius absinthi Marshall, A. rosae Haliday AND A. urticae Haliday (HYMENOPTERA: BRACONIDAE: APHIDIINAE)
}

\author{
Ana S. Mitrovski-Bogdanović* and Petar M. Radojičić \\ University of Kragujevac, Faculty of Science, Institute of Biology and Ecology, \\ Radoja Domanovića 12, 34000 Kragujevac, Republic of Serbia \\ *Corresponding author; E-mail: amitrovski@kg.ac.rs
}

(Received February 1, 2017; Accepted March 30, 2017)

\begin{abstract}
In this paper, we applied traditional and geometric morphometric methods to analyze variability in wing size and wing shape among species Aphidius absinthi Marshall, A. rosae Haliday and A. urticae Haliday. These taxa represent closely related species with different biological and ecological characters. For the morphometric analyses, we used a sample of 52 female specimens that were collected during the period 2009-2013, on different localities in Serbia. Traditional morphometric analyses revealed statistical significance in stigma shape discrimination of analysed taxa. Our geometric morphometric analyses also confirmed that major contribution to the wing shape variation had the changes in length of the radial sector and stigma shape. Combining the traditional and geometric morphometric analyses, we confirmed the validity of the wing characters previously used in taxonomic studies of the genus Aphidius.
\end{abstract}

Key words: Aphidius absinthi, A. rosae, A. urticae, geometric morphometry.

\section{INTRODUCTION}

The genus Aphidius Nees, with about 100 described species worldwide (TOMANOVIĆ et al., 2007) and about 35 detected species in Europe (STARÝ, 1970), is one of the the largest within the subfamily Aphidiinae (Hymenoptera: Braconidae). All species are solitary endoparasitoids of aphids. Many Aphidius species have a great potential as biocontrol agents in biological control programs (HAGVAR and HoFsVANG, 1991), so a success of these programs depends on their correct identification. Because of that, there are many papers relating to the taxonomy of Aphidius species (EADY, 1969; STARÝ, 1973; PUNGERL, 1983; PENNACCHIO, 1989; MesChElOFF and RoSEn, 1990; TAKADA, 1998; TOMANOviĆ and Starý, 2001; KAVALLIERATOS et al., 2001, 2006; TOMANOVIĆ et al., 2003, 2004, 2007, 2013; Kos et al., 2011; JAMHOUR et al., 2016). However, due to a great variability of morphological characters, many taxonomic problems were encountered in the genus Aphidius. One of them is taxonomical position of Aphidius absinthi_Marshall, A. rosae Haliday and A. urticae Haliday, which represent closely related species with different biological and ecological characters. A. absinthi is parasitoid of Macrosiphoniella Del Guecio species, A. rosae represents a highly specialized species restricted to Macrosiphum rosae Linnaeus, while A. urticae has wide host range and parasitizes on Acyrthosiphon Mordvilko, Amphorophora Buckton, Macrosiphum Passerini and Microlophium Mordvilko species. According to the last 
revision, these taxa mostly differ from each other by the number of antennal segments, length of metacarpal vein, number of costulae on anterolateral area of petiole and host range (STARÝ, 1973).

The purpose of this study was to analyse morphological differentiation in the forewing size and shape among species $A$. absinthi, A. rosae and A. urticae by traditional morphometry and geometric morphometric analyses and to test the validity of morphological characteristics, such as wing venation, previously used for their identification (STARÝ, 1973; PENNACCHIO, 1989; TOMANOVIĆ et al., 2003, 2007).

\section{MATERIAL AND METHODS}

\section{Traditional morphometry}

For the morphometric analyses, we used a sample of 52 female specimens that were collected during the period 2009-2013, on different localities in Serbia (Table 1). Plant samples bearing both live and mummified aphid hosts, were collected for parasitoids rearing. Samples of live aphids were preserved in $90 \%$ ethanol and $75 \%$ lactic acid at a ratio of 2:1 (EASTOP and VAN EMDEN, 1972) for later identification. The remaining aphids were maintained in the laboratory until parasitoid emergence. Mummies, each attached to a small leaf piece, were placed separately in small plastic boxes and put inside a growth cabinet. On the lid of each box there was a circular opening covered with muslin for ventilation in order to maintain the conditions inside the boxes similar to those in the growth cabinet $\left(22.5^{\circ} \mathrm{C}\right.$, relative humidity 65\%, 16L:8D) (KAVALLIERATOS et al., 2001). All analyzed specimens were boiled in $10 \% \mathrm{KOH}$, dissected, and mounted in Canada balsam (STARÝ, 1970). The external structure of emerged parasitoids was studied using a ZEISS Discovery V8 stereomicroscope.

Three continuous characters were used for the morphological characterization of the analyzed specimens, as follows: stigma length (STL), stigma width (STW) and the length of R1 vein $=$ metacarpal (R1L) (Fig. 1). All the characters were presented in terms of a ratio in order to eliminate effect of size, also allowing direct comparison of the obtained results with other analyses (Table 2). Morphological terminology for wing diagnostic characters used in this study is based on SHARKEY and WHARTON (1997).

Table 1. List of the Aphidius species used in analyses.

\begin{tabular}{|c|c|c|c|c|}
\hline Parasitoid & Host aphid & Host plant & Country & $\begin{array}{c}\text { No. of } \\
\text { specimens }\end{array}$ \\
\hline $\begin{array}{l}\text { Aphidius } \\
\text { absinthi }\end{array}$ & $\begin{array}{l}\text { Macrosiphoniella } \\
\text { sp. }\end{array}$ & $\begin{array}{l}\text { Centaurea } \\
\text { rhenana }\end{array}$ & Serbia & 16 \\
\hline Aphidius rosae & $\begin{array}{l}\text { Macrosiphum } \\
\text { rosae }\end{array}$ & Rosa sp. & Serbia & 19 \\
\hline $\begin{array}{l}\text { Aphidius } \\
\text { urticae }\end{array}$ & $\begin{array}{l}\text { Macrosiphum } \\
\text { euphorbiae }\end{array}$ & $\begin{array}{l}\text { Euphorbia } \\
\text { esula }\end{array}$ & Serbia & 17 \\
\hline
\end{tabular}

Analysis of variance (ANOVA) was used to test the statistical significance of differences in variation of STL/STW and STL/R1L, while Tukey's test was done for their pairwise comparison. Canonical Variate Analysis (CVA) was performed to determine which of analysed ratio characters would contribute significantly to species discrimination. Percentage of the correct identification was calculated by Discriminant Function Analysis 
(DFA). All standard statistical analyses were performed in Statistica 6 software package (STATSOFT, 2001).

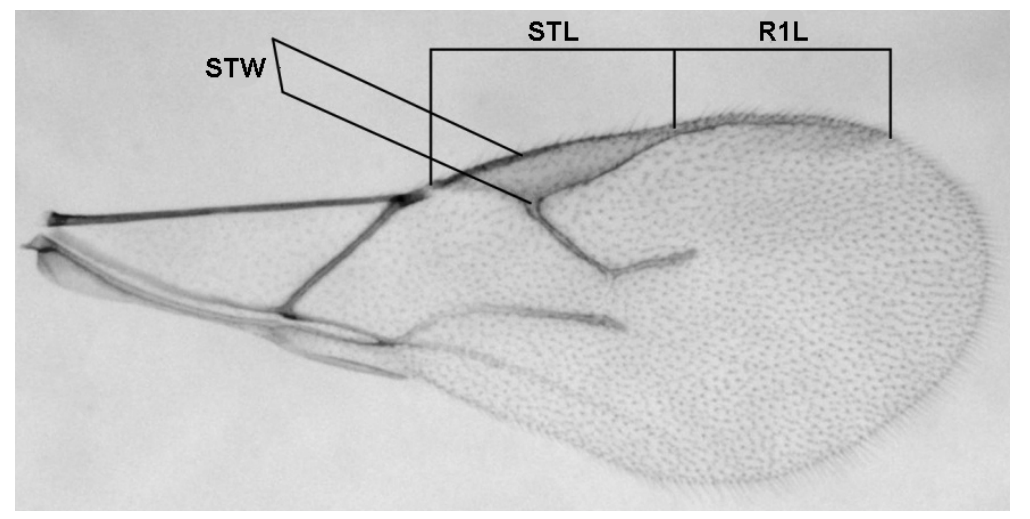

Fig. 1. Analysed characters on a left forewing of Aphidius absinthi female (STL - stigma length, STW - stigma width, R1L - length of metacarpal (R1) vein).

Table 2. List of characters for morphometric analyses.

\begin{tabular}{lll}
\hline Character code & Type & Description \\
\hline STL/STW & Ratio & Stigma length/stigma width \\
STL/R1L & Ratio & Stigma length/length of R1 vein \\
\hline
\end{tabular}

\section{Geometric morphometrics}

The geometric morphometrics approach was applied to explore and quantify variations in wing size and wing shape of 52 female specimens (ZELDITCH et al., 2012). The same sample was used for both, traditional morphometry and geometric morphometric methods (Table 1). Left forewing of each specimen was detached, mounted in Canada balsam and photographed using a Leica System Microscope DM2500 with a Leica DFC490 Digital Camera. We selected 13 specific landmarks to describe the wing size and shape. The positions of the landmarks are given in Fig. 2, while their definitions are presented in Table 3. All landmarks were digitized using TpsDig software (ROHLF, 2005). Landmarks were superimposed by the Generalized Procrustes Analysis (ROHLF and SLICE, 1990; BOOKSTEIN, 1991). Procrustes coordinates were used as shape variables in following statistical analyses.

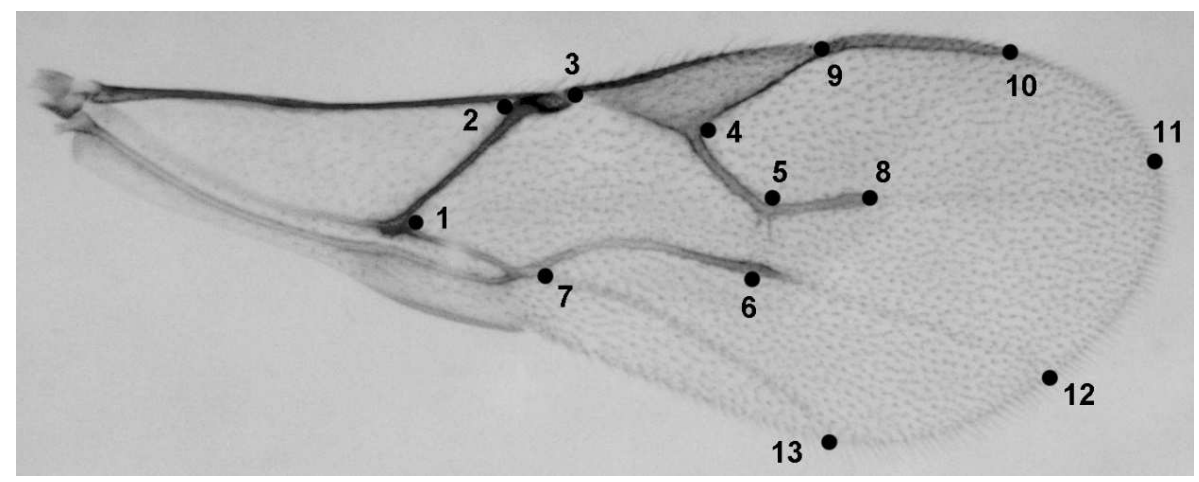

Fig. 2. Landmarks scored on a left forewing of Aphidius absinthi female.

To estimate wing size, we computed the centroid size (CS), a geometric measure of the size which reflects the amount of dispersion around the centroid of the landmark configuration (BOOKSTEIN, 1991). The variation in the wing size (CS) among different species 
from the genus Aphidius was analyzed by one-way ANOVA. Post-hoc pairwise comparison for wing size was done by Tukey's test. Multivariate analysis of variance (MANOVA) on the full set of the shape variables was performed to analyze a differences in the wing shape of parasitoids belonging to different species (ZELDITCH et al., 2012). All statistical analyses were performed with the Statistica 6 software package (STATSOFT, 2001).

Table 3. Landmarks descriptions

\begin{tabular}{cl}
\hline Landmarks & Description \\
\hline $1,2,7$ & proximal part of the forewing \\
$3,4,9$ & length and width of the stigma \\
$4,5,8$ & radial sector \\
5,6 & length of r-m vein \\
9,10 & $\begin{array}{l}\text { length of R1 vein (= metacarpal) } \\
\text { distal part of the forewing (projections of the radial sector, medial } \\
\text { and cubital vein to the edge of the wing) }\end{array}$ \\
\hline
\end{tabular}

Canonical variate analysis (CVA), which reduces within group variances and increases between group divergences, was performed to explore a divergence of the wing shape among the three species using software MorphoJ (KLINGENBERG, 2011). Discriminant function analysis (DFA) was used to evaluate the accuracy of classsification by original and cross-validation percentages of the cases (MANLY, 1997).

\section{RESULTS AND DISCUSSION}

\section{Traditional morphometry}

The Analysis of variance showed statistically significant differences in stigma shape described by STL/STW (ANOVA: $F=4.302, \mathrm{MS}=0.4606$, $\mathrm{df}=2, P=0.01$ ), in contrast to the other ratio character STL/R11 (ANOVA: $F=0.1015, \mathrm{MS}=0.01050, \mathrm{df}=2, P=0.90$ ). The results of Tukey's test indicated on statisticaly significant differences in STL/STW character only between species $A$. absinthi and A. urticae ( $\mathrm{p}=0.0142$ ).

Also, the results of Canonical Variate Analysis confirmed that ratio character STL/STW has higher contribution to the species discrimination (Table 4). The results of Discriminant function analysis (DFA) based on analysed ratio characters, indicate about 50\% correct assignment of specimens to the a priori designated species. The following percentages for the correct classification of individuals per species were found: A. absinthi $50.00 \%, A$. rosae $47.37 \%$ and $A$. urticae $52.94 \%$.

Table 4. Standardized canonical discriminant function coefficients for Aphidius species

\begin{tabular}{lll}
\hline Character code & CV1 & CV2 \\
\hline STL/STW & $\mathbf{1 . 1 8 3 8 5 6}$ & -0.059801 \\
STL/R1L & -0.686106 & -0.966617 \\
\hline Eigenval & 0.262315 & 0.003484 \\
\hline Cum.Prop & 0.986892 & 1.000000 \\
\hline
\end{tabular}




\section{Geometric morphometrics}

A significant variation in the wing centroid size was found among the Aphidius species (ANOVA: $F=9.146$, df $=2, P<0.0001$ ). We found that $A$. absinthi females have larger wings (mean wing $\mathrm{CS}=1379.38 \pm 44.65$ ) than $A$. rosae females (mean wing $\mathrm{CS}=$ $1292.31 \pm 182.48$ ) and $A$. urticae females with the smallest wing size (mean wing CS = $1171.65 \pm 144.96)$. Tukey's test indicated statisticaly significant differentiation in wing size between $A$. absinthi and A. urticae ( $\mathrm{p}=0.0003)$, as well as between $A$. rosae and A. urticae $(\mathrm{p}=0.0345)$. A significant difference in the wing shape (MANOVA: Wilks' Lambda $=$ $0.017149, F=8.4$, df $1=44$, df2 $=56, P<0.0001$ ) among species was also found.

Correct classification of individuals per species based on wing shape was provided as the following percentages (the first and the second values in brackets represent the original and cross-validation, respectively): A. absinthi $100 \%$ (62.5\%), A. rosae 100\% (100\%) and $A$. urticae $100 \%$ (65\%).

Canonical variate analysis (CVA) revealed that the first canonical axis explained $90.60 \%$ of the total variability in wing shape. A. absinthi and A. urticae were clustered together and clearly discriminated from $A$. rosae by the position of radial sector and $\mathrm{r}-\mathrm{m}$ vein (Fig. 3). Specimens of $A$. rosae have elongated radial sector (described by landmarks 4, 5 and 8 ) and shorter r-m vein (described by landmarks 5 and 6). However, A. absinthi and A. urticae specimens are separated along the second canonical axis, which explained $9.40 \%$ of the total variability in wing shape. The main shape changes that discriminate these species are related to the stigma shape (described by landmarks 3, 4 and 9) and R1 vein (described by landmarks 9 and 10). In contrast to A. urticae, the specimens of $A$. absinthi have wider stigma, shorter R1 vein and wider distal part of the wing (described by landmarks 11, 12 and 13).

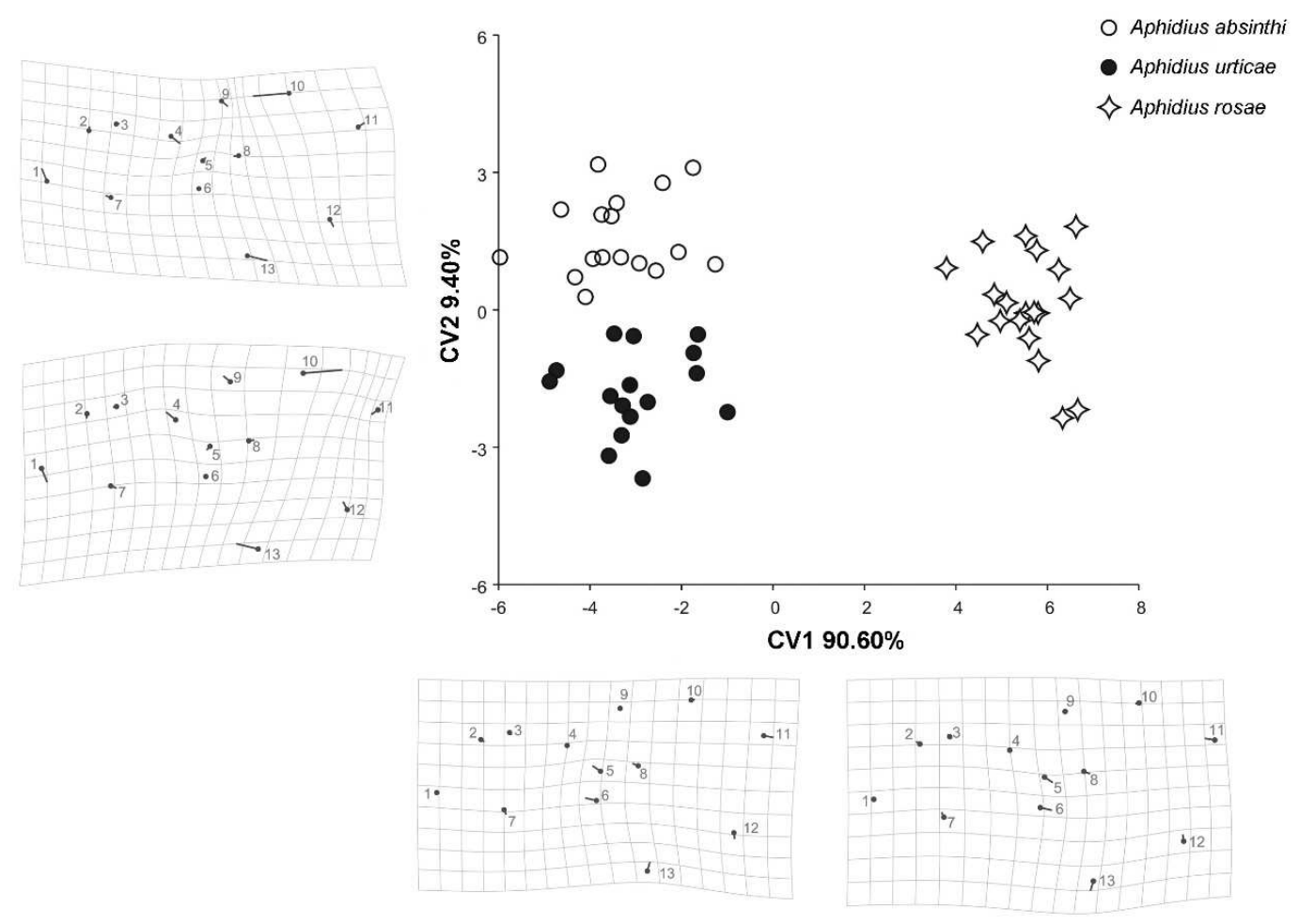

Fig. 3. Ordination of the Aphidius specimens in the morpho-space. The thin-plate spline deformation grids illustrate the wing shape changes correlated with the first and the second canonical axis.

Previously, taxonomic studies within a genus Aphidius were based mainly on a few morphological characters such as: wing venation, sculpturing on the anterolateral area of 
petiole, number of antennal segments, shape and chaetotaxy of the female genitalia, tentorial index, number of maxillary and labial palpomeres (SMITH, 1944; EADY, 1969; STARÝ, 1973; TOMANOVIĆ et al., 2003, 2007).

Based on traditional and geometric morphometric analyses our results confirmed that all three analyzed taxa, A. absinthi, A. rosae and A. urticae are true species. According to the results of traditional morphometry, we found that the stigma shape has statistically significant influence on the species discrimination. Geometric morphometric analysis also confirmed that the major variation in the wing shape consisted of changes in the length of the radial sector and $r-m$ vein, as well as in the stigma shape itself. The shape of the stigma, the length of R1 vein and the ratio between the length of stigma and the length of the R1 vein were comonly used as valid characters for the morphological characterization and separation within the genus Aphidius (StARÝ, 1973; PENNACCHIO, 1989; KAVALliERATOS et al., 2001; RAKHSHANI et al., 2008; PETROVIĆ et al., 2010; Kos et al., 2011; TOMANOVIĆ et al., 2003, 2013, 2014).

In contrast to the last revision of the genus Aphidius, where A. absinthi and A. rosae belong to the A.rosae group (STARÝ, 1973), we found that $A$. absinthi has clustered together with $A$. urticae and clearly discriminate from $A$. rosae, which specimens have elongated radial sector and shorter $\mathrm{r}-\mathrm{m}$ vein. However, we also found clear differences between A. absinthi and A. urticae in stigma shape, length of $\mathrm{R} 1$ vein, as well as in wing size.

\section{CONCLUSIONS}

We found clear differences among species A. absinthi, A. rosae and A. urticae in the wing size, as well as in the wing shape by the position of radial sector and r-m vein, stigma shape and the ratio between the length of stigma and the length of the R1 vein.

Combining the traditional and geometric morphometric analyses, we confirmed the reliability of previosly used wing characters for Aphidius identification, also indicating that $\mathrm{r}$ $m$ vein could be used as a new character in identification keys.

This paper represents a contribution to the resolving of some taxonomical problems within the genus Aphidius, but the clarification of the status of many other aggregations or cryptic species requires further morphological and molecular researches.

\section{Acknowledgements}

The authors are grateful to professors Željko Tomanović and Ana Ivanović (Faculty of Biology, University in Belgrade) for their helpfull collaboration in this work. Also, we would like to thank to proffesor Olivera Petrović-Obradović (Faculty of Agriculture, University of Belgrade) for identification of the aphids. This research was supported by the Grant No. III43001 (The Ministry of Education, Science and Technological Development of the Republic of Serbia).

\section{References:}

[1] Bookstein, F.L. (1991): Morphometric tools for landmark data. Cambridge University Press, Cambridge, 433 pp.

[2] EADY, R.D. (1969): A new diagnostic character in Aphidius (Hymenoptera: Braconidae) of special significance in species on pea aphid. Proceedings of the Royal Entomological Society of London, B 38: 165-173. 
[3] EAstop, V.F., EMden, H.F. (1972): The insect material. In: VAN EMdEN H. F. (ed.): Aphid Technology. Academic Press, London, 45 pp.

[4] Hagvar, E.B., Hofsvang, T. (1991): Aphid parasitoids (Hymenoptera: Aphidiidae): biology, host selection, and use in biological control. Biocontrol News and Informations 12: $13-41$.

[5] Jamhour, A., Mitrović, M., Petrović, A., Starý, P., Tomanović, Ž. (2016): Revisiting the Aphidius urticae s. str. group: re-description of Aphidius rubi Stary and A. silvaticus Stary (Hymenoptera: Braconidae: Aphidiinae). Zootaxa 4178 (2): 278-288.

[6] Kavallieratos, N.G., Lykouressis, D.P., Sarlis, G.P., Stathas, G.J., Sanchis Segovia, A., Athanassiou, C.G. (2001): The Aphidiinae (Hymenoptera: Ichneumonoidea: Braconidae) of Greece. Phytoparasitica 29: 306-340.

[7] Kavallieratos, N.G., Tomanović, Ž., Sarlis, G.P., Fasseas, C., Emmanouel, N.E. (2006): A review of the genus Aphidius Nees in Greece (Hymenoptera: Braconidae: Aphidiinae) with the description of a new species. Journal of Natural History 40: 11791197.

[8] KLINGEnBerg, C.P. (2011): MorphoJ: an integrated software package for geometric morphometrics. Molecular Ecology Resources 11: 353-357.

[9] Kos, K., Petrović, A., Kavallieratos, N.G., Ivanović, A., ToŠEvski, I., Jakše, J., Trdan, S., TOMANOvić, Ž. (2011): On the Identity of Cereal Aphid Parasitoid Wasp Aphidius uzbekistanicus, Aphidius rhopalosiphi, and Aphidius avenaphis (Hymenoptera: Braconidae: Aphidiinae) by Examination of COI Mitochondrial Gene, Geometric Morphometrics, and Morphology. Annals of the Entomological Society of America 104 (6): 1221-1232.

[10] Manly, B.F.J. (1997): Randomization, Bootstrap and Monte Carlo Methods in Biology. 2nd edition, Chapman \& Hall, New York, 424 pp.

[11] Mescheloff, E., Rosen, D. (1990): Biosystematic studies on Aphidiidae of Israel (Hymenoptera: Ichneumonidea) 4. The genera Pauesia, Dieretus, Aphidius and Diaretiella. Israel Journal of Entomology 24: 51-91.

[12] Pennacchio, F. (1989): The Italian species of the genus Aphidius Nees (Hymenoptera: Braconidae: Aphidiinae). Bollettino del Laboratorio di Entomologia Agraria Filippo Silvestri 46: 75-106.

[13] Petrović, A., Tomanović, Ž., Kavallieratos, N.G., Starý, P., Žıikić, V. (2010): Aphidius geranii sp n. (Hymenoptera: Braconidae) from Southeast Europe - a new member of the Aphidius urticae s. str. Group. Entomologica Fennica 20 (4): 233-238.

[14] PungerL, N.B. (1983): Variability in characters commonly used to distinguish Aphidius species (Hymenoptera: Aphidiidae). Systematic Entomology 8: 425-430.

[15] Rakhshani, E., Talebi, A.A., Starý, P., Tomanović, Ž., Kavallieratos, N.G., MANZARI, S. (2008): A review of Aphidius Nees (Hymenoptera: Braconidae: Aphidiinae) in Iran: host associations, distribution and taxonomic notes. Zootaxa 1767: 37-54.

[16] RohLF, F. J. (2005): TpsDig program, version 2.04, Ecology and Evolution, SUNY at Stony Brook, available from http://life.bio.sunysb.edu/morph/

[17] Rohlf, F.J., Slice, D.E. (1990): Extensions of the Procrustes method for the optimal superimposition of landmarks. Systematic Zoology 39: 40-59. 
[18] Sharkey, M.J., Wharton, R.A. (1997): Morphology and terminology. In: Wharton, R. A., Marsh, P.M., Sharkey, M.J. (eds.) Manual of the New World Genera of the family Braconidae (Hymenoptera). Special Publication 1, International Society of Hymenopterists, Washington, DC, pp.19-37.

[19] Smith, C.F. (1944): The Aphidiinae of North America (Braconidae: Hymenoptera). Ohio State University, Columbus, Contribution in Zoology and Entomology 6:1-154.

[20] STARÝ, P. (1970): Biology of Aphid Parasites (Hymenoptera: Aphidiidae) with Respect to Integrated Control Series Entomologica, 6. Junk Publishers, Hague, The Netherlands, $291 \mathrm{pp}$.

[21] Starý, P. (1973): A review of the Aphidius species (Hymenoptera: Aphidiidae) of Europe. Annotationes zoologicae et botanicae (Bratislava) 84: 1-85.

[22] StatSoft, 2001. Statistica (data analysis software system), version 6. Statsoft, Inc., Tulsa, Oklahoma, USA, available from http://www.statsoft.com/

[23] TAKADA, H. (1998): A review of Aphidius colemani (Hymenoptera: Braconidae: Aphidiinae) and closely related species indigenous to Japan. Applied Entomology and Zoology 33 (1): 59-66.

[24] Tomanović, Ž., Kavallieratos, N.G., Athanassiou, C.G., Petrović O., STANISAVLJEVIĆ, LJ. (2004): A new Aphidius species (Hymenoptera: Braconidae: Aphidiinae) from high-montane areas of southeastern Europe. Phytoparasitica 32: 221225.

[25] Tomanović, Ž., Kavallieratos, N.G., Starý, P., Athanassiou, C.G., Žıikić, V., Petrović-Obradović, O., SARlis, G.P. (2003): Aphidius Nees aphid parasitoids (Hymenoptera, Braconidae, Aphidiinae) in Serbia and Montenegro: tritrophic associations and key. Acta Entomologica Serbica 8 (1/2): 15-39.

[26] Tomanović, Ž., Kavallieratos, N.G., StarÝ, P., ŽIKIĆ, V., Tomić, V.T., Lučić, L.R. (2007): Redescription of two species of Aphidiinae (Hymenoptera: Braconidae) from high mountain areas of south-eastern Europe, with biological and biogeographical notes on co-occurring guild members. Entomologica Fennica 18: 36-45.

[27] Tomanović, Ž., Kos, K., Petrović, A., Starý, P., Kavallieratos, N.G., Žıikić, V., JAKŠE, J., TRDAN, S., IVANOVIĆ, A. (2013): The relationship between molecular variation and variation in the wing shape of three aphid parasitoid species: Aphidius uzbekistanicus Luzhetzki, Aphidius rhopalosiphi De Stefani Perez, and Aphidius avenaphis (Fitch) (Hymenoptera: Braconidae: Aphidiinae). Zoologischer Anzeiger 252 (1): $41 / 47$.

[28] Tomanović, Ž., Petrović, A., Mitrović, M., Kavallieratos, N.G., Starý, P., Rakhshani, E., Rakhshanipour, M., Popović, A., Shukshuk, A.H., Ivanović, A. (2014): Molecular and morphological variability within the Aphidius colemani group with redescription of Aphidius platensis Brethes (Hymenoptera: Braconidae: Aphidiinae). Bulletin of Entomological Research 104: 552-565.

[29] Tomanović, Ž., Starý, P. (2001): Aphidius linosiphonis sp. nov. (Hymenoptera: Braconidae:Aphidiinae), a new member of the aphid parasitoid guild associated with Galium. Zootaxa 6: 1-4.

[30] Zelditch, M.L., Swiderski, D.L., SheEts, H.D. (2012): Geometric Morphometrics for Biologists: A Primer. 2nd edition. Elsevier, Academic Press, San Diego, 448 pp. 